\title{
PENDAMPINGAN PEMANFAATAN PUPUK ORGANIK BIOSLURRY UNTUK RUMAH PANGAN LESTARI DI DESA MONTONGSARI KABUPATEN KENDAL
}

\author{
Florentina Kusmiyati $^{*}$, Susilo Budiyanto ${ }^{1}$, Bagus Herwibawa ${ }^{1}$ \\ ${ }^{I}$ Departemen Pertanian, Fakultas Peternakan dan Pertanian, Universitas Diponegoro, \\ Kompl. drh. R. Soejono Koesoemowardojo, Tembalang - Semarang 50275 \\ *Penulis Korespodensi : fkusmiyati@live.undip.ac.id
}

\begin{abstract}
Abstrak
Ketahanan pangan mensyaratkan kondisi tercukupinya pangan bagi seluruh elemen masyarakat, berkualitas, aman, beragam, bergizi, merata, serta mudah dijangkau. Rumah tangga memiliki peran penting sebagai satu diantara banyak faktor pendukung terwujudnya ketahanan pangan nasional, misalnya dengan pembentukan Rumah Pangan Lestari (RPL) yang berwawasan pertanian organik. Selain memiliki nilai ekonomi, kesehatan, dan ekologi, pembentukan RPL juga akan mengoptimalkan pemanfaatan pekarangan dan ruang-ruang sempit di sekitar rumah. Artikel ini merupakan rangkuman dari satu diantara beberapa kegiatan Kuliah Kerja Nyata - Pembelajaran Pemberdayaan Masyarakat (KKN-PPM UNDIP) di desa Montongsari, kabupaten Kendal. Kegiatan ini bertujuan untuk memberdayakan kelompok ibu-ibu rumah tangga yang tidak bekerja, untuk memanfaatkan limbah biogas atau biosurry sebagai pupuk organik dalam budidaya tanaman dengan teknik vertikultur di sekitar rumah. Metode yang digunakan adalah survei, penyuluhan, pelatihan, dan pendampingan pembuatan RPL dengan memanfaatkan bioslurry. Hasil kegiatan ini memberikan dampak positif bagi masyarakat, yaitu mulai timbul kesadaran dan perubahan perilaku masyarakat. Bioslurry yang sebelumnya belum dimanfaatkan, dapat diaplikasikan sebagai pupuk organik. Lahan kosong di sekitar rumah dan sepanjang kiri-kanan jalan yang selama ini tidak dimanfaatkan, mulai dimanfaatkan sebagai kawasan yang menunjang pangan masyarakat. Lingkungan yang dulu terkesan gersang berubah menjadi lebih asri. Oleh sebab itu untuk mendukung keberlanjutan RPL, diperlukan keinginan yang serius dan tindakan nyata dari pemerintah dan masyarakat.
\end{abstract}

Kata kunci: Bioslurry, Kelestarian Lingkungan, Organik, Pangan, Rumah Pangan Lestari

\begin{abstract}
Food security exist when all people at all times have access to sufficient, safe, and nutritious food. Households have an important role in national food security, by creating the Sustainable Food Reserve Gardens based on organic principles. It has economic, health, and ecological benefits. Sustainable Food Reserve Gardens also will optimize the spaces arround the houses. This article is a summary of one of the Student Community Service - Community Empowerment Learning of Diponegoro University activities in Montongsari village, Kendal Regency. This program aims was to empower the group of housewives to use biogas residue or bioslurry as organic fertilizer in verticulture arround the houses. The methods used were survey, extension, training, and outreach in application of bioslurry organic fertilizer for Sustainable Food Reserve Gardens. This program had positive impact for the community, including the emergence of awarenees and behavior changes of community. Bioslurry can be applied as organic fertilizer. Spaces arround the houses can provide accessibility of fresh food for community. The village seems to change to become more beautiful. Therefore, to support the Sustainable Food Reserve Gardens, it requires serious commitment and real action of the government and community.
\end{abstract}

Keywords: Bioslurry, Environmental Sustainability, Organic, Food, Sustainable Food Reserve Gardens

\section{PENDAHULUAN}

\subsection{Analisis Situasi}

Desa Montongsari merupakan satu diantara 16 desa di kecamatan Weleri, kabupaten Kendal, provinsi Jawa Tengah dan memiliki tiga dusun, yaitu dusun Montongkulon, Montongkrajan dan Montongtambak (Rizkiana, 2011). Desa Montongsari terletak pada ketinggian \pm 10 meter di atas permukaan laut (mdpl), menyebabkannya beriklim panas dengan curah hujan rata-rata $0-453 \mathrm{~mm} /$ bulan. Jumlah penduduk sekitar 2.737 orang yang terdiri dari $811 \mathrm{KK}$ dengan tingkat pendidikan sebagian besar lulusan SMA dan lulusan SMP, serta sebagian kecil lulusan SD (BPS-Kendal, 2014). Desa Montongsari merupakan sentra produksi padi di Kendal, sehingga juga diharapkan mampu memberikan kontribusi besar terhadap ketahanan 
pangan nasional. Ketahanan pangan saat ini telah menjadi isu prioritas karena mensyaratkan kondisi tercukupinya pangan bagi seluruh elemen masyarakat, berkualitas, aman, beragam, bergizi, dan merata, serta mudah dijangkau (Hamzah dan Lestari, 2016). Terpenuhinya pangan pada setiap rumah tangga merupakan tujuan utama, sehingga menjadi satu diantara banyak faktor pendukung terwujudnya ketahanan pangan nasional. Upaya mewujudkan ketahanan pangan dapat dilakukan mulai tingkat rumah tangga melalui pembentukan Rumah Pangan Lestari (RPL) yang berwawasan pertanian organik (Purwanti et al., 2012).

RPL merupakan rumah yang memanfaatkan pekarangan secara intensif melalui pengelolaan sumberdaya lokal secara bijaksana, sehingga ketersediaan bahan pangan terjamin dan memiliki keberlanjutan dengan tetap memelihara dan meningkatkan kualitas, termasuk tata nilai dan keanekaragaman (Sunarti et al., 2015). Selain itu, pembentukan RPL saat ini juga seharusnya didukung dengan Gerakan Perempuan untuk Optimalisasi Pekarangan (GPOP) (Surtinah dan Nizar, 2017). Pekarangan merupakan sebidang lahan yang berada di sekitar rumah dan dibatasi oleh ukuran luas, yaitu sempit, sedang, dan besar (Azra et al., 2014). Meskipun demikian pemanfaatan pekarangan secara bijak dapat menjadi bentuk implementasi ketahanan pangan, karena fungsinya akan bertambah menjadi lahan pertanian produktif. Pekarangan rumah diharapkan mampu memenuhi kebutuhan pangan di tingkat rumah tangga, dimana pemanfaatan pekarangan berukuran sempit dapat dilakukan dengan teknik vertikultur. Beberapa hal yang perlu diperhatikan dalam penerapan konsep pertanian lahan sempit adalah 1) ketersediaan pekarangan di sekitar rumah, 2) pengembangan tanaman-tanaman produktif dengan teknologi budidaya yang ramah lingkungan, dan 3) penyuluhan, pelatihan serta pendampingan tentang teknologi tepat guna.

Kandang kambing komunal yang terdapat di desa Montongsari memiliki potensi kotoran kambing yang belum dimanfaatkan secara optimal. Berdasarkan potensi tersebut Tim KKN-PPM UNDIP tahun 2017 telah melakukan pendampingan dalam pembangunan reaktor biogas berkapasitas $4 \mathrm{~m}^{3}$, dimana $0,8-1,6 \mathrm{~m}^{3}$ gas yang dihasilkan tiap hari telah dimanfaatkan oleh keluarga pra-sejahtera. Gas yang dihasilkan tersebut berasal dari 20-40 kg kotoran kambing, dan menghasilkan $18 \mathrm{~kg}$ limbah biogas atau bioslurry. Upaya tersebut dilakukan untuk memenuhi kebutuhan pupuk organik berkualitas bagi masyarakat dan petani di desa Montongsari. Bioslurry sangat dibutuhkan sejak kebijakan pemerintah dan animo masyarakat mengarah pada penerapan sistem pertanian organik. Bioslurry didapatkan setelah gas terpisah dengan kotoran melalui reaktor (Herlina et al., 2015), dan merupakan pupuk yang baik, kaya unsur hara makro dan bahan organik yang berpengaruh pada tingkat kesuburan tanah (Debebe dan Itana, 2016). Selain itu, bioslurry juga meningkatkan aktivitas dan populasi mikroorganisme tanah (Novitamala et al., 2015). Meskipun demikian, bioslurry di desa Montongsari belum dimanfaatkan secara optimal oleh masyarakat sekitar. Masyarakat pedesaan sebenarnya telah lama memanfaatkan lahan pekarangan dengan budidaya tanaman untuk kebutuhan sehari-hari, tetapi pemanfaatannya masih bersifat sambilan untuk mengisi waktu luang. Padahal bila dikelola dengan baik tentu akan memberikan nilai tambah bagi kesehatan, ekologi, sosial, dan ekonomi masyarakat.

Masyarakat desa Montongsari sebagai mitra memiliki rumah dengan luas pekarangan bervariasi, bahkan ada yang tidak memiliki pekarangan, namun ingin menghasilkan bahan pangan dari sekitar rumahnya. Budidaya tanaman di pekarangan secara konvensional yang selama ini dilakukan oleh kelompok ibu-ibu rumah tangga menghadapi beberapa kendala, antara lain sulitnya mendapatkan media tanam yang subur dan harga pupuk yang mahal. Oleh sebab itu sebagian besar pemanfaatan pekarangan hanya sekedar hobi, karena bila dihitung biaya untuk membeli media tanam dan pupuk tidak lebih ekonomis bila dibandingkan dengan membeli bahan pangan di pasar. Berdasarkan situasi tersebut maka Tim KKN-PPM UNDIP telah memberikan penyuluhan, pelatihan, dan pendampingan pemanfaatan pupuk organik bioslurry untuk RPL. Pembentukan RPL dengan teknik vertikultur diharapkan mampu mengoptimalkan pemanfaatan pekarangan berukuran sempit. Selain itu juga diharapkan mitra akan menggemari budidaya tanaman secara vertikultur yang berwawasan pertanian organik, karena lebih sehat dan memiliki nilai estetika lebih tinggi. Pemanfaatan pekarangan untuk budidaya tanaman pangan juga dapat dijadikan gaya hidup untuk mencukupi kebutuhan pangan rumah tangga, sehingga berkontribusi pada ketahanan pangan rumah tangga dan nasional.

\subsection{Permasalahan}

Permasalahan yang dihadapi oleh mitra adalah sebagai berikut.

1) Rendahnya pengetahuan tentang pemanfaatan pupuk organik bioslurry untuk RPL,

2) Belum adanya pendampingan tentang pemanfaatan pupuk organik bioslurry untuk RPL,

3) Kurangnya pemahaman bahwa pekarangan rumah juga dapat memberikan manfaat bagi kesehatan, ekologi, sosial, dan ekonomi.

\section{TARGET DAN LUARAN}

\subsection{Target yang dicapai}

Pengetahuan dan keterampilan masyarakat desa Montongsari meningkat dengan adanya kegiatan KKNPPM UNDIP. Selain itu, masyarakat juga mampu memanfaatkan pupuk organik bioslurry untuk RPL pada pekarangan-pekarangan sempit di sekitar rumah dengan teknik vertikultur. Beberapa model konstruksi vertikultur yang dibuat antara lain model rak kayu, rak bambu, pot dengan gantungan tali, pot yang digantung di dinding, dimana model-model tersebut 
menyesuaikan keadaan pekarangan, peralatan dan bahan yang tersedia, serta ide-ide yang muncul dari masyarakat sendiri. Kegiatan selanjutnya adalah persiapan media tanam, persemaian benih, dan perawatan tanaman, hingga panen.

\subsection{Luaran yang dicapai}

Luaran adalah publikasi ilmiah dalam bentuk artikel yang dipublikasikan. Publikasi tersebut dapat dibaca oleh banyak masyarakat umum, masyarakat industri, sivitas akademika, pemerintah, dan pemangku kepentingan lainnya.

\section{METODE PELAKSANAAN}

Mitra kegiatan KKN-PPM UNDIP adalah masyarakat desa Montongsari, khususnya kelompok ibu-ibu rumah tangga. Kegiatan ini dilaksanakan mulai bulan Juli sampai Agustus 2017. Metode-metode yang dilaksanakan untuk mencapai target dan luaran meliputi sosialisasi, penyuluhan, pelatihan, pemberian bantuan paket teknologi, pendampingan, dan evaluasi sebagai berikut.

1) Sosialisasi merupakan kegiatan paling awal untuk menyampaikan rencana kegiatan pada masyarakat, dengan hasil kesepakatan yang berisi tentang jadwal kegiatan dan tanggung jawab masingmasing pihak, yaitu Tim KKN-PPM UNDIP dan masyarakat untuk menyukseskan keseluruhan rangkaian kegiatan.

2) Penyuluhan untuk meningkatkan pengetahuan tentang pemanfaatan pupuk organik bioslurry untuk RPL dengan teknik vertikultur, dilakukan melalui presentasi untuk memberikan pengertian, pemahaman, kesadaran, dan motivasi kepada masyarakat, serta menunjukkan bahwa teknologi yang akan dibuat tersebut mudah, murah, dan membawa dampak bagi kesehatan masyarakat, serta kelestarian lingkungan. Kegiatan ini memberikan kesempatan diskusi atau tukar pengalaman antara Tim KKN-PPM dan masyarakat, sehingga minat masyarakat semakin meningkat untuk memanfaatkan pupuk organik bioslurry.

3) Pelatihan pemanfaatan pupuk organik bioslurry untuk RPL dengan teknik vertikultur, dengan memperkenalkan kepada masyarakat alat dan bahan yang digunakan, dari pembuatan konstruksi vertikultur, persiapan media tanam, persemaian benih, dan perawatan tanaman, hingga panen.

4) Pemberian bantuan paket teknologi berupa alat dan bahan guna memanfaatkan pupuk organik bioslurry untuk RPL dengan cara vertikultur, sehingga pengetahuan dan teknologi yang sudah ditransfer dapat dilaksanakan secara berkelanjutan.

5) Pendampingan bagi masyarakat yang tertarik memanfaatkan pupuk organik bioslurry untuk RPL dengan teknik vertikultur, dari menyemai benih, perawatan tanaman, hingga panen. Metode ini bertujuan agar masyarakat benar-benar merasakan manfaat dari kegiatan KKN-PPM UNDIP ini, dan dapat merasakan bahwa kegiatan KKN-PPM UNDIP ini tidak bersifat sewaktu, namun kapanpun masyarakat memerlukan bantuan peningkatan pengetahuan dan teknologi, maka Tim KKN-PPM UNDIP siap menjadi fasilitator.

6) Evaluasi dilakukan berdasarkan instrumen pengukuran kegiatan KKN-PPM UNDIP tentang pemanfaatan pupuk organik bioslurry untuk RPL dengan teknik vertikultur, berupa kuesioner yang harus diisi sebelum dan sesudah kegiatan dilaksanakan.

\section{HASIL DAN PEMBAHASAN \\ 4.1 Hasil Kegiatan}

Kegiatan sosialisasi, penyuluhan, pelatihan, pemberian bantuan paket teknologi, pendampingan, dan evaluasi oleh Tim KKN-PPM UNDIP ini diikuti oleh masyarakat desa Montongsari, khususnya kelompok ibu-ibu rumah tangga. Kegiatan secara keseluruhan berjalan baik dengan partisipasi masyarakat yang sangat antusias mengikuti kegiatan-kegiatan yang telah diagendakan bersama ini. Antusias tersebut dapat dilihat dari respon yang diberikan oleh masyarakat melalui banyaknya pertanyaan yang diajukan, karena ketertarikannya untuk mengetahui manfaat bioslurry dan cara pemanfaatannya. Selain itu, masyarakat juga sangat senang dengan adanya pemberian paket teknologi yang diberikan oleh Tim KKN-PPM UNDIP, berupa alat dan bahan guna memanfaatkan pupuk organik bioslurry untuk RPL dengan teknik vertikultur, serta petunjuk praktis berupa selebaran atau brosur.
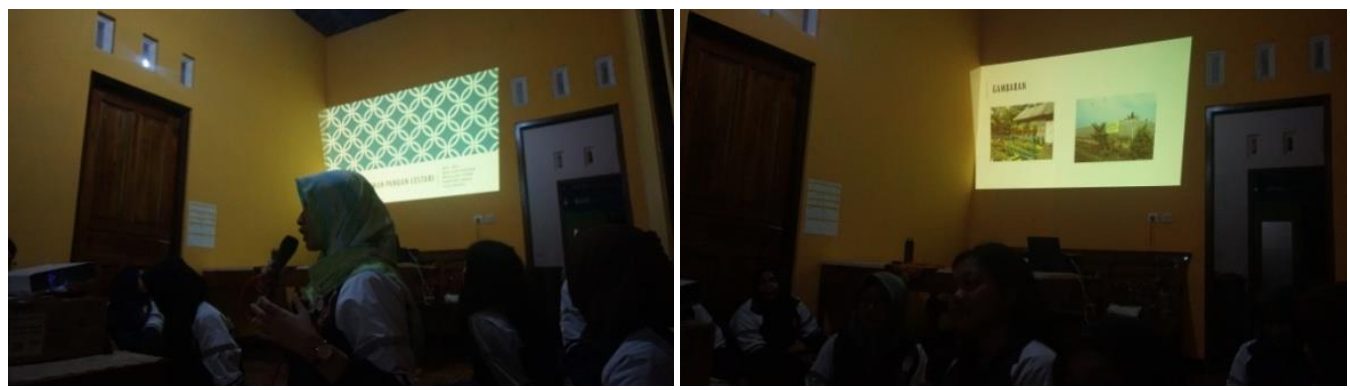

Gambar 1. Sosialisasi kegiatan KKN-PPM UNDIP ke masyarakat desa Montongsari, khususnya dusun Montongtambak didampingi ketua RW 03 

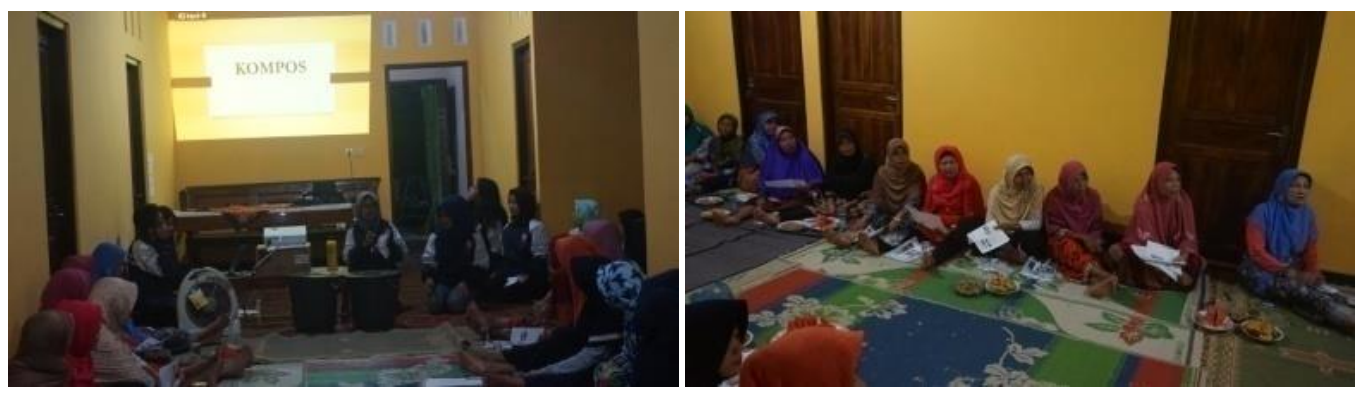

Gambar 2. Penyuluhan kepada masyarakat desa Montongsari, khususnya ibu-ibu rumah tangga
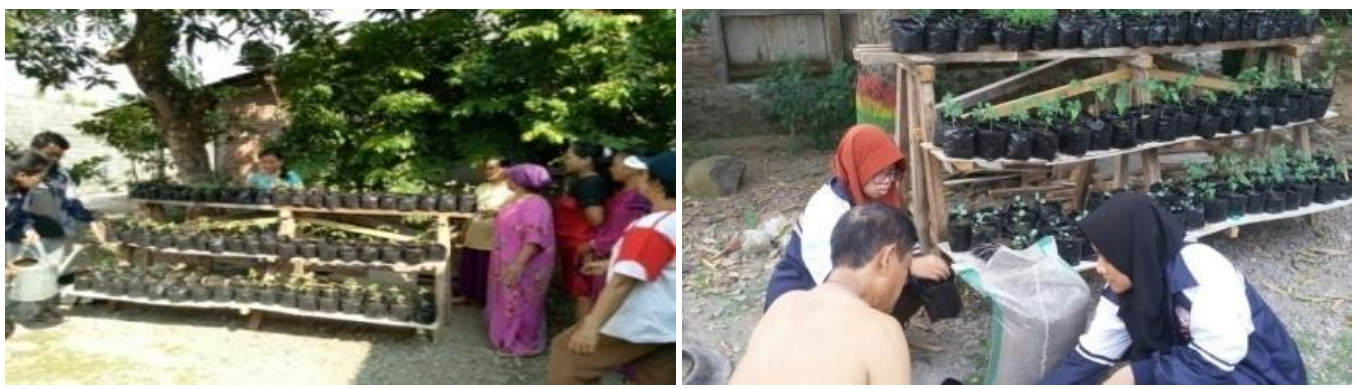

Gambar 3. Pelatihan pemanfaatan pupuk organik bioslurry untuk RPL dengan cara vertikultur

Tabel 1. Hasil pengukuran sebelum kegiatan dilaksanakan

\begin{tabular}{|c|c|c|c|c|c|}
\hline No & Pertanyaan & \multicolumn{2}{|c|}{ Ya } & \multicolumn{2}{|c|}{ Tidak } \\
\hline 1 & Apakah anda memiliki pengetahuan tentang bioslurry? & 8 & $\%$ & 92 & $\%$ \\
\hline 2 & Apakah anda mengetahui tentang istilah Rumah Pangan Lestari (RPL) ? & 8 & $\%$ & 92 & $\%$ \\
\hline 3 & Apakah anda berminat memanfaatkan pekarangan rumah untuk RPL? & 47 & $\%$ & 53 & $\%$ \\
\hline 4 & Apakah anda memiliki pengetahuan budidaya tanaman secara vertikultur? & 16 & $\%$ & 84 & $\%$ \\
\hline 5 & Apakah anda pernah mencoba budidaya tanaman secara organik? & 39 & $\%$ & 61 & $\%$ \\
\hline 6 & Apakah anda sulit untuk mendapatkan pupuk organik? & 16 & $\%$ & 84 & $\%$ \\
\hline 7 & $\begin{array}{l}\text { Apakah anda berminat untuk mengikuti pelatihan budidaya tanaman yang sehat dan } \\
\text { ramah lingkungan? }\end{array}$ & 24 & $\%$ & 76 & $\%$ \\
\hline 8 & Apakah KKN-PPM UNDIP bermanfaat bagi anda ? & 100 & $\%$ & 0 & $\%$ \\
\hline
\end{tabular}

Tabel 2. Hasil pengukuran setelah kegiatan

\begin{tabular}{|c|c|c|c|c|c|}
\hline No & Pertanyaan & \multicolumn{2}{|c|}{ Ya } & \multicolumn{2}{|c|}{ Tidak } \\
\hline 1 & Apakah anda memiliki pengetahuan tentang bioslurry? & 76 & $\%$ & 24 & $\%$ \\
\hline 2 & Apakah anda mengetahui tentang istilah Rumah Pangan Lestari (RPL) ? & 100 & $\%$ & 0 & $\%$ \\
\hline 3 & Apakah anda berminat memanfaatkan pekarangan rumah untuk RPL? & 84 & $\%$ & 16 & $\%$ \\
\hline 4 & Apakah anda memiliki pengetahuan budidaya tanaman secara vertikultur? & 92 & $\%$ & 8 & $\%$ \\
\hline 5 & Apakah anda pernah mencoba budidaya tanaman secara organik? & 92 & $\%$ & 8 & $\%$ \\
\hline 6 & Apakah anda sulit untuk mendapatkan pupuk organik? & 8 & $\%$ & 92 & $\%$ \\
\hline 7 & $\begin{array}{l}\text { Apakah anda berminat untuk mengikuti pelatihan budidaya tanaman yang sehat dan } \\
\text { ramah lingkungan? }\end{array}$ & 92 & $\%$ & 8 & $\%$ \\
\hline 8 & Apakah KKN-PPM UNDIP bermanfaat bagi anda ? & 100 & $\%$ & 0 & $\%$ \\
\hline
\end{tabular}

Tabel 3. Peningkatan pengetahuan dan keterampilan setelah mengikuti kegiatan

\begin{tabular}{|c|c|c|c|}
\hline No & Pertanyaan & $\begin{array}{l}\text { Peningkatan } \\
\text { Pengetahuan }\end{array}$ & Keterangan \\
\hline 1 & Apakah anda memiliki pengetahuan tentang bioslurry? & $68 \%$ & Meningkat \\
\hline 2 & Apakah anda mengetahui tentang istilah Rumah Pangan Lestari (RPL)? & 92 & Meningkat \\
\hline 3 & Apakah anda berminat memanfaatkan pekarangan rumah untuk RPL ? & 37 & Meningkat \\
\hline 4 & Apakah anda memiliki pengetahuan budidaya tanaman secara vertikultur? & 76 & Meningkat \\
\hline 5 & Apakah anda pernah mencoba budidaya tanaman secara organik? & 53 & Meningkat \\
\hline
\end{tabular}


$6 \quad$ Apakah anda sulit untuk mendapatkan pupuk organik ?

7 Apakah anda berminat untuk mengikuti pelatihan budidaya tanaman yang

sehat dan ramah lingkungan?

8 Apakah KKN-PPM UNDIP bermanfaat bagi anda ?

$\begin{array}{rrrl}8 & \% & & \text { Menurun } \\ 68 & \% & & \text { Meningkat } \\ 0 & \% & & \text { Tetap }\end{array}$

\subsection{Pembahasan}

Hasil pengukuran pada Tabel 1 menjelaskan bahwa $47 \%$ responden berminat memanfaatkan pekarangan rumah untuk RPL, dan 39\% dari antaranya telah memiliki pengalaman budidaya tanaman secara organik. Angka yang lebih rendah dari 50\% tersebut disebabkan karena kurangnya pengetahuan tentang bioslurry, RPL, dan vertikultur. Selain itu ada anggapan bahwa pemanfaatan pupuk organik bioslurry untuk RPL dengan teknik vertikultur sulit, hal ini ditunjukkan dari $76 \%$ responden yang tidak berminat untuk mengikuti pelatihan budidaya tanaman yang sehat dan ramah lingkungan. Anggapan bahwa kegiatan ini sulit dilakukan harus dirubah, karena bioslurry yang dihasilkan reaktor biogas di desa Montongsari belum dimanfaatkan, selain itu kondisi pekarangan rumah yang bervariasi namun secara umum memiliki ukuran yang sempit, tepat bila dilakukan pembentukan RPL dengan teknik vertikultur. Tabel 2 menjelaskan bahwa setelah kegiatan dilaksanakan terjadi peningkatan pengetahuan, minat, dan pengalaman dalam hal pemanfaatkan pupuk organik bioslurry untuk RPL dengan teknik vertikultur. Hasil kegiatan ini sudah menjawab target dari kegiatan KKN-PPM UNDIP yaitu meningkatkan pengetahuan dan keterampilan masyarakat desa Montongsari.

Perubahan perilaku masyarakat desa Montongsari terjadi seiring dengan peningkatan pengetahuan dan keterampilan setelah mengikuti kegiatan (Tabel 3). Pendampingan pemanfaatan pupuk organik bioslurry untuk RPL dengan teknik vertikultur yang dilakukan oleh Tim KKN-PPM UNDIP, merupakan teknologi budidaya tanaman yang ramah lingkungan, sehingga menjaga kualitas dan kesehatan produk pertanian yang dihasilkan sesuai standar pangan organik. Selain itu, masyarakat berharap bahwa pemanfaatan bioslurry yang diperkenalkan dan ditularkan oleh Tim KKNPPM UNDIP tidak hanya tentang pemanfaatan pupuk organik guna menunjang RPL dengan cara vertikultur, namun juga teknologi granulalisasi, pengemasan, serta pemasarannya, sehingga juga dapat dimanfaatkan oleh masyarakat di luar desa Montongsari.

\section{KESIMPULAN}

Masyarakat desa Montongsari memberikan respon positif, ditunjukkan dengan partisipasi aktif masyarakat dalam seluruh rangkaian kegiatan yang diinisiasi bersama Tim KKN-PPM UNDIP. Pengetahuan dan keterampilan masyarakat tentang pemanfaatan pupuk organik bioslurry untuk RPL dengan teknik vertikultur mengalami peningkatan, setelah mengikuti kegiatan sosialisasi, penyuluhan, pelatihan, pendampingan, dan evaluasi bersama Tim
KKN-PPM UNDIP. Penyuluhan, pelatihan, dan pendampingan secara langsung oleh Tim KKN-PPM UNDIP berpengaruh terhadap minat masyarakat untuk mengimplementasikan pengetahuan dan keterampilan yang dimilikinya, selain itu pemberian paket teknologi berupa alat dan bahan guna memanfaatkan pupuk organik bioslurry untuk RPL dengan teknik vertikultur, juga sangat membantu menumbuhkan semangat masyarakat untuk langsung menerapkan pengetahuan dan teknologi yang sudah ditularkan oleh Tim KKN-PPM UNDIP. Kegiatan ini sangat bermanfaat bagi masyarakat, khususnya sebagai upaya penyediaan pangan yang sehat di tingkat rumah tangga dengan mengoptimalkan fungsi pekarangan rumah.

\section{UCAPAN TERIMA KASIH}

Terima kasih disampaikan kepada Direktorat Riset dan Pengabdian kepada Masyarakat (DRPM) Kementerian Riset, Teknologi dan Pendidikan Tinggi yang membiayai kegiatan ini pada skema Kuliah Kerja Nyata Pembelajaran dan Pemberdayaan Masyarakat (KKN - PPM), tahun 2017 dan Lembaga Penelitian dan Pengabdian Masyarakat (LPPM) Universitas Diponegoro yang telah menjadi fasilitator dalam kegiatan ini.

\section{DAFTAR PUSTAKA}

Azra, A. L. Z., Arifin, H. S., Astawan, M., \& Arifin, N. H. S. (2014). Analisis Karakteristik Pekarangan dalam Mendukung Penganekaragaman Pangan Keluarga di Kabupaten Bogor. Jurnal Lanskap Indonesia, 6(2), 1-11.

BPS-Kendal (2014). Kecamatan Weleri dalam Angka (p. 101). Kendal: Badan Pusat Statistik Kabupaten Kendal

Debebe, Y., \& Itana, F. (2016). Comparative study on the effect of applying biogas slurry and inorganic fertilizer on soil properties, growth, and yield of white cabbage (Brassica oleracea var. capitata f. alba). Journal of Biology, Agriculture and Healthcare, 6(19), 19-26.

Hamzah, A., \& Lestari, S. U. (2016). Rumah Pangan Lestari Organik sebagai Solusi Peningkatan Pendapatan Keluarga. Jurnal Akses Pengabdian Indonesia, 1 (1), 65-72.

Herlina, N., Herianto, H., \& Hiron, N. (2015). IbM penyuluhan rancang bangun dan analisis bangunan digester biogas tipe fixed dome skala rumah tangga pada kelompok ternak trijaya dan masyarakat desa Situmandala, kecamatan Rancah, kabupaten Ciamis. Jurnal Siliwangi, 1 (1), 33-38.

Novitamala, C.B., Suwerda, B., \& Werdiningsih, I. (2015). Efektifitas berbagai dosis bio-slurry 
sebagai bumbu kompos terhadap waktu pembentukan dan kualitas kompos di dusun Gadingharjo, Donotirto, Kretek, Bantul. Sanitasi, Jurnal Kesehatan Lingkungan, 7(2), 51-58.

Purwantini, T.B., Saptana, \& Suharyono, S. (2012). Program Kawasan Rumah Pangan Lestari (KRPL) di Kabupaten Pacitan: Analisis Dampak dan Antisipasi ke Depan. Analisis Kebijakan Pertanian, 10(3), 239-256.

Rizkiana, I. A. (2011). Tradisi Upacara Obong pada Masyarakat Kalang di Desa Montongsari Kecamatan Weleri Kabupaten Kendal. Skripsi. Universitas Negeri Semarang.

Sunarti, Endriani, \& Ajidirman (2015). Pemberdayaan Masyarakat berbasis Teknologi Model Rumah Pangan Lestari di Kecamatan Kumpeh Ulu. Jurnal Pengabdian Pada Masyarakat, 30(1), 19.

Surtinah, \& Nizar, R. (2017). Pemanfaatan Pekarangan Sempit dengan Hidroponik Sederhana di Pekanbaru. Jurnal Pengabdian Kepada Masyarakat, 23(2), 274-278. 